\title{
Regulation of Luteal Function by Post-ovulatory Luteinizing Hormone Secretion in 4-Day and 5-Day Cycling Rats*
}

\author{
Inoru Hashimoto, Katsuya Aizawa, Yuichi Seya, Yasushi Komoda, \\ Kohji Higashino, Ken-ichiro Mutoh and Mitsumori Kawaminami \\ Laboratories of Veterinary Physiology and Anatomy, \\ Kitasato University \\ School of Veterinary Medicine and Animal Sciences, \\ Towada-shi, Aomori 034, Japan \\ *Preliminary reports of these findings appeared in \\ Jpn J Anim Reprod (1982) 28: Suppl p. 44 and \\ Folia Endocrinol Jpn (1983) 59: 535.
}

(Accepted for publication September 16, 1988)

\begin{abstract}
Summary. Concerning effects of post-ovulatory anti-LH serum (aLH) administration on luteal progesterone $(\mathrm{P})$ secretion and reactivity to prolactin (PRL), comparisons were made between 4- and 5-day cycles. Plasma $P$ declined by 6:00 hr on diestrus (D) in control 4-day cycling rats and by 18:00 hr on day D in control 5-day cycling rats. Daily injections of aLH from 8:00 hr on estrus (E) in 4-day cycles did not alter $\mathrm{P}$ secretion. However, aLH injections from 8:00 hr on metestrus (M) prolonged $\mathrm{P}$ secretion up to 18:00 hr on day $\mathrm{D}$, while aLH injections from 19:00 hr on day $\mathrm{M}$ failed to prolong $\mathrm{P}$ secretion. In 5-day cycles, aLH injections from 8:00 hr on day $E$ or 19:00 hr on day $M$ prolonged $P$ secretion. Control 4-day cycling rats responded to PRL injections from 8:00 hr on day $M$ with elevated $P$ secretion and persistent leukocytic vaginal smears for 9-10 days, but they failed to respond to PRL injections from 19:00 hr on day D. Control 5-day cycling rats also failed to respond to PRL injections from 19:00 hr on day D. Injections of aLH from 8:00 hr on day $M$ in 4-day cycles preserved the full luteal reactivity at 19:00 hr on day D. The aLH injections from 19:00 hr on day M maintained the full luteal reactivity at 19:00 hr on day $\mathrm{D}$ in 5-day cycles, but not in 4-day cycles. At 18:00 hr on day $\mathrm{D}$, changes in the fine structure of the lutein cells from control and aLH-treated 4-day cycling rats were correlated to those in plasma $\mathrm{P}$ levels. These results indicate (1) tonic LH levels on day E of 4-day cycles "enhance" luteal P secretion, (2) tonic levels of LH secreted on day M suppress luteal function, which has a structural basis, (3) the suppressive effect is imposed at least $11 \mathrm{hr}$ later in 5-day cycles than in 4-day cycles. KEY WORDS; RAT ESTROUS CYCLE, LH SECRETION, PROLACTIN, LUTEAL FUNCTION, LUTEOLYSIS.
\end{abstract}

Jpn J Anim Reprod 34, 249-260, 1988

\section{Introduction}

Uchida et al. (1969) suggested that the metestrous rise in luteal progesterone secretion in 4-day cycling rats is autonomous and independent of pituitary gonadotropin secretion. The difference in amplitude and/or duration of progesterone secretion from a new crop of corpora lutea between 4- and 5-day estrous cycles has since been clarified (Roser and Block, 1969; Furudate et al., 1975; van der Schoot and de Greef, 1976; Nequin et al., 1979, Kaneko et al., 1986). Evidence suggesting regulation of luteal progesterone secretion by postovulatory luteinizing hormone (LH) and prolactin (PRL) secretion has been described for both 4- (Boehm et al., 1984; Sanchez-Criado et al., 1986) and 5-day cycling rats (van der Schoot and Uilenbroek, 1983; Boehm et al., 1984). In ad- 
dition, a series of experiments conducted in this laboratory have demonstrated that the 5-day cycling rat with prolonged luteal progesterone secretion exhibits an attenuated magnitude of ovulatory LH surge accompanied by an augmented preovulatory PRL release, compared to the 4-day cycling animal (Hashimoto et al., 1987). Furthermore, the magnitude of preovulatory LH surge is causally related to the amplitude and/or duration of progesterone secretion from a new crop of corpora lutea (Okudaira et al., 1983; Hashimoto et al., 1984). On the other hand, corpora lutea of the rat estrous cycle begin to lose their ability to respond to PRL within approximately $60 \mathrm{hr}$ after ovulation (Acker and Alloiteau, 1968). Nikitovitch-Winer and Everett (1958) have reported that corpora lutea of the 5-day cycle remain reactive to PRL later in their life span than do corpora lutea of the 4-day cycle. Post-ovulatory hypophysectomy (deprivation of both LH and PRL) sustains the luteal reactivity to $\mathrm{PRL}$ for a prolonged period (Acker and Alloiteau, 1968). In the present investigation, therefore, effects of post-ovulatory LH deprivation (anti-LH serum administration) on both luteal progestational function and reactivity to PRL were compared between the 4- and 5-day cycling rats. In addition, an attempt was made to characterize, by electron microscopy, the appearance of the luteal cells from 4-day cycling rats treated with anti-LH serum (aLH) and to correlate these changes with those in plasma progesterone levels.

\section{Materials and Methods}

\section{Animals}

Adult female Holtzman rats (3-4 months old) inbred in this laboratory were kept in a temperature-controlled room $\left(22^{\circ} \mathrm{C}\right)$ that was artificially illuminated daily from 5:00 to 19:00 hr. They were provided rat chow (CA-1; Clea Japan, Inc., Tokyo) and water ad libitum. Vaginal smears were examined every morning, and only those rats that had shown more than 3 consecutive regular 4- or 5-day cycles were selected for the present investigation. The 5-day cycling rats showed nucleated vaginal smears on the second day of diestrus and vaginal cornification on both proestrus and estrus. In this colony, approximately 30 and $60 \%$ of the rats exhibited regular 4and 5-day cycles, respectively; the remaining animals showed irregular cycles (Furudate et al.,
1975). Ordinary pseudopregnancy (PSP) was induced by mechanical stimulation of the uterine cervix with a glass rod on the evening of proestrus. Throughout all the experiments, day of ovulation (vaginal estrus) was designated as day 0 .

Anti-LH Serum (aLH) and Normal Rabbit Serum (NRS)

Anti-LH serum was generated in a adult male Japanese White rabbit using ovine LH (NIHLH-S 20) as the antigen. Titer of aLH was determined by an ovulation suppression study. Six or seven 4-day cycling rats were given intravenously a single dose of $0.0025,0.005,0.01$ or $0.02 \mathrm{ml}$ of aLH at 12:30 and 17:00 hr on proestrus under light ether anesthesia, and autopsied at 11:30 hr on the following day (estrus). The oviducts were examined for oocytes under a dissecting microscope. The total dose of aLH was plotted on a logarithmic scale against an observed incidence of ovulation blockade. The amount of aLH that blocked ovulation in $50 \%$ of the animals was determined and expressed as 1 unit. The value obtained for the aLH preparation was 50 unit $/ \mathrm{ml}$. The cross-reactivity of the antiserum with either NIADDK-rPRL-RP-1 or NIADDK-rFSH-RP-1 was less than $0.3 \%$ in the radioimmunoassay (RIA) system. The ovarian weight augmentation study in immature rats demonstrated that the biological activity of human chorionic gonadotropin (hCG) is not suppressed by the aLH preparation. Prior to use, aLH and NRS were each treated with charcoal as previously described (Kaneko et al., 1986). The charcoal-treated aLH and NRS contained less than $1.0 \mathrm{ng}$ progesterone, $0.25 \mathrm{ng} 20 \alpha$-hydroxypregn-4-en-3-one and $10 \mathrm{pg}$ estradiol per $\mathrm{ml}$. Both aLH and NRS were diluted 5 times with sterile isotonic saline. The diluted solution was divided into $0.5 \mathrm{ml}$ portions and kept frozen $\left(-80^{\circ} \mathrm{C}\right)$ until intraperitoneally injected daily at 8:00 and/or 19:00 hr at $0.5 \mathrm{ml}$ (aLH; 5 unit).

\section{Prolactin}

Ovine PRL (38.9 IU/mg; Sigma Chemical Co., St. Louis, MO, USA) was dissolved in $0.05 \mathrm{M}$ borate buffer $(\mathrm{pH} 8.2)$ at a concentration of 20 $\mathrm{IU} / \mathrm{ml}$. The hormone was subcutaneously injected daily at 8:00 and/or 19:00 hr at $10 \mathrm{IU}$.

\section{RIA of Progesterone}


Plasma progesterone was extracted by the method described by Hashimoto et al. (1975). The residues were subjected to Sephadex LH-20 (Pharmacia Fine Chemicals, Piscataway, NJ, USA) column chromatography for separation of progesterone, as described by Kaneko et al. (1986). The steroid was determined in duplicate by dextran-charcoal RIA (Hashimoto et al., 1975). The workable range of assay was $25-750 \mathrm{pg}$ for progesterone. The intra- and interassay coefficients of variation, calculated from repeated results on pooled samples, varied between 7 and $14 \%$.

\section{Electron Microscopy}

Whole ovaries were placed on a watch glass cooled on an ice bath, and a few new corpora lutea with bright reddish color were isolated with the aid of magnifying glasses (Optikon; Chemical Rubber Co., Cleveland, Ohio, USA) and dissecting needles. Corpora lutea were fixed overnight in $0.1 \mathrm{M}$ phosphate buffer ( $\mathrm{pH} 7.3$ ) containing $1.5 \%$ paraformaldehyde and $0.5 \%$ glutaraldehyde at $4^{\circ} \mathrm{C}$. After post-fixation in either $1 \% \mathrm{OsO}_{4}$ in $0.1 \mathrm{M}$ phosphate buffer (pH 7.3) at $4^{\circ} \mathrm{C}$ for $1.5 \mathrm{hr}$ or $2 \% \mathrm{OsO}_{4}$ water solution at $4{ }^{\circ} \mathrm{C}$ for $48 \mathrm{hr}$ (Osmication; Sawano and Fujita, 1980), corpora lutea were dehydrated through a graded series of ethanol at room temperature and embeded in epoxy resin by the routine method. Ultra-thin sections (600-800 $\AA$ ) were stained with either combined uranyl acetate and lead citrate or uranyl acetate alone (osmicated sections) and examined with a Hitachi HS-8 electron microscope.

\section{Experimental Protocols}

The first experiment was conducted to determine effects of aLH administration on vaginal cyclicity. Four- and 5-day cycling rats received aLH injections from 8:00 hr on day 0 through either 19:00 hr on day 1 or 8:00 hr on day 2, and vaginal smears were examined daily.

In the second experiment, effects of postovulatory aLH administration on plasma progesterone levels were investigated in both 4 - and 5-day cycling rats. Four- and 5-day cycling animals were divided into 4 and 3 groups, respectively. Each group received NRS or aLH injections at appropriate post-ovulatory stages indicated in the results (see Table 1). Blood samples were collected, under light ether anesthesia, from a small incision made at the tip of the tail into a heparinized micro-sampling pipet (Corning Co., Midland, Mich, USA) at various times indicated in the results (see Table 1).

In the third experiment, effects of post-ovulatory deprivation on luteal reactivity to $\mathrm{PRL}$ in both 4- and 5-day cycling rats were evaluated in terms of both plasma progesterone levels and persistency of leukocytic vaginal smears. Four- and 5-day cycling rats were divided into 7 and 3 groups, respectively. Each group received NRS or aLH injections during appropriate post-ovulatory stages and PRL administration which began 11-12 hr after the last injection of NRS or aLH and continued until $8: 00 \mathrm{hr}$ on day 6 , as indicated in the results (see Table 2). Vaginal smears were examined every morning, and blood samples were colleced at $13: 00 \mathrm{hr}$ on day 6 by the method described above.

In the fourth experiment, 4-day cycling rats treated with either NRS or aLH from 8:00 hr on day 1 were decapitated at 18:00 hr on day 2 and examined for fine structure of the luteal cells.

\section{Statistics}

Changes in plasma progesterone levels within each treatment group over time and differences in the steroid levels at each time point between treatment groups were each evaluated using oneway analysis of variance followed by least significant difference tests. These tests were also used to determine the significance of the differences in persistency of luekocytic vaginal smears between treatment groups. To test the null hypothesis that a population correlation coefficient between plasma progesterone levels and persistency of leukocytic vaginal smears is zero, Student's $t$ tests were used. A $p$ value below 0.05 was considered significant.

\section{Results}

\section{Vaginal Cyclicity of aLH-Treated Rats}

Injections of NRS altered vaginal cyclicity in neither 4- or 5-day cycling rats, as shown in Fig. 1. In aLH-treated 4- and 5-day cycling animals, however, leukocytic smears persisted for 3-6 days. Thus, aLH injections significantly prolonged persistency of leukocytic smears $(p<0.01)$. No significant differences in persistency of the smears were observed among the three groups of aLHtreated rats. The mean persistency of leukocytic smears and a standard error for all the aLH. 


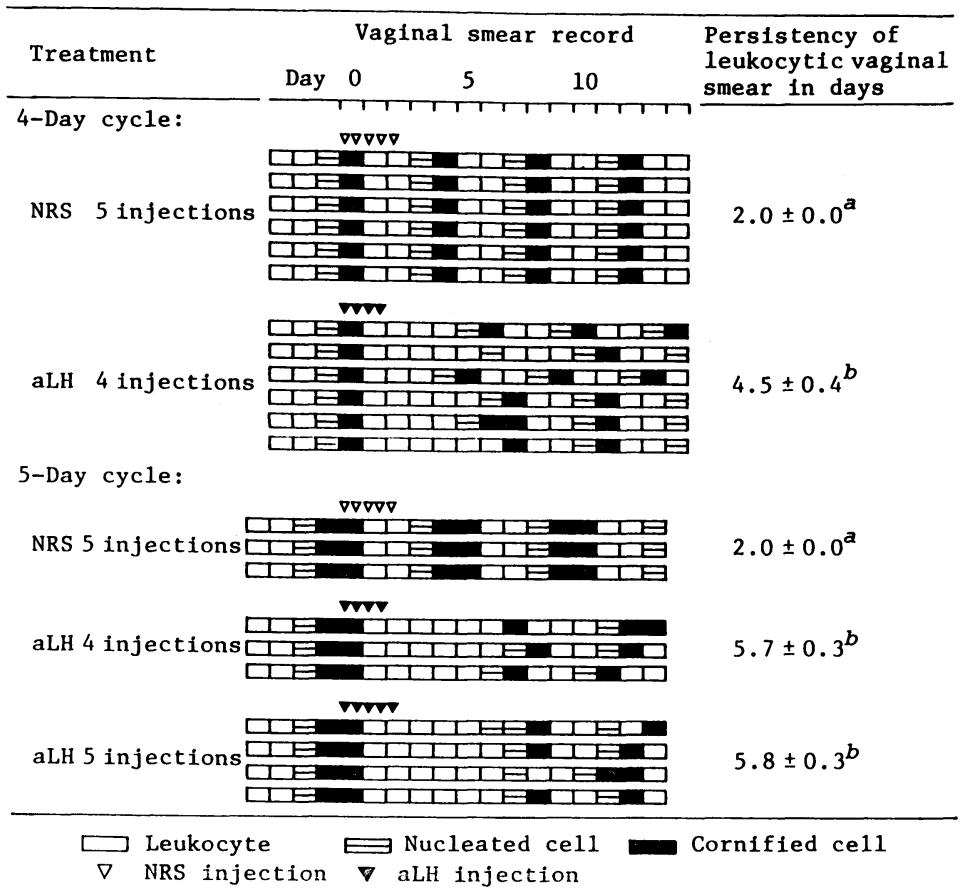

Fig. 1. Vaginal smear records in individual 4- and 5-day cycling rats treated with normal rabbit serum (NRS) or anti-LH serum (aLH). Day of ovulation (vaginal estrus) is designated as day 0 . Both NRS and aLH were diluted 5 times with sterile isotonic saline and intraperitoneally injected daily at 8:00 and/or 19:00 hr at $0.5 \mathrm{ml}$ (aLH; 5 unit) from 8:00 hr on dy 0 . Values are the means and a standard error. abThe means with the different alphabetic letters are significantly different from each other $(p<0.01)$.

treated animals was $5.2 \pm 0.3$ days $(n=13)$, as shown in Table 2.

Plasma Progesterone Levels in aLH-Treated Rats

As shown in Table 1, the highest progesterone level in 4-day cycling rats given NRS injections from 8:00 hr on day 0 was found during the initial measurements at 20:00 hr on day 1. Progesterone levels in these rats decreased significantly from $20: 00 \mathrm{hr}$ on day 1 to $6: 00 \mathrm{hr}$ on day $2(p<0.01)$ and remained low at 18:00 $\mathrm{hr}$ on day 2. Levels of the steroid in 4-day cycling rats treated with aLH from 8:00 hr on day 0 were comparable to those in control NRS-treated animals during days 1 and 2, and remained low at 6:00 hr on day 3. At both 6:00 and 18:00 hr on day 2, progesterone levels in 4-day cycling rats injected with aLH from 8:00 hr on day 1 were significantly higher than those in the control animals $(p<0.01)$. At 18:00 hr on day 2, however, levels of the steroid in 4-day cycling rats injected with aLH from as late as 19:00 hr on day 1 were similar to those in control animals.

Progesterone levels in control 5-day cycling rats treated with NRS from 8:00 hr on day 0 were not significantly different from those in control 4-day cycling animals at both 20:00 hr on day 1 and 18:00 hr on day 2. At 6:00 hr on day 2, however, levels of the steroid were significantly higher in control 5-day cycling rats than in control NRStreated 4-day cycling animals $(p<0.01)$. Progesterone levels in 5-day cycling rats treated with aLH from $8: 00 \mathrm{hr}$ on day 0 were not significantly different from those in control 5-day cycling animals at either 20:00 hr on day 1 or $6: 00 \mathrm{hr}$ on day 2. At 18:00 hr on day 2, however, progesterone levels in these aLH-treated 5-day cycling rats remained significantly higher than levels in control animals $(p<0.01)$, and tended to be high also at 6:00 hr on day 3. At 18:00 hr on day 2, 
levels of progesterone again remained significantly higher in 5-day cycling rats given aLH from 19:00 hr on day 1 than in control animals $(p<0.01)$.

Persistence of Leukocytic Vaginal Smears in PSP Leukocytic vaginal smears persisted for $11.4 \pm$ 0.4 days $(n=7)$ in PSP induced in 4-day cycling rats and for $12.8 \pm 0.6$ days $(n=5)$ in PSP induced in 5-day cycling animals. No significant differences in the persistence of the leukocytic smear (duration of PSP) were apparent between the rats with two cycle lengths. The combined mean value was $12.0 \pm 0.4$ days $(n=12)$, as shown in Table 2.

Persistency of Leukocytic Vaginal Smears and Plasma Progesterone Levels in Rats Treated with Combined aLH and PRL

As shown in Table 2, control NRS-pretreated 4-day cycling rats responded to PRL injections from $8: 00 \mathrm{hr}$ on day 2 with persistent leukocytic vaginal smears for a prolonged period comparable to the duration of PSP, although all the animals showed nucleated smears on day 3 . The NRSpretreated 4-day cycling rats injected with PRL from as late as $19: 00 \mathrm{hr}$ on day 2 showed an additional vaginal cycle, then exhibited leukocytic smears for 10-13 days. Contrarily, in 4-day cycling rats pretreated with aLH from $8: 00 \mathrm{hr}$ on day 0, PRL injections from 19:00 hr on day 2 maintained leukocytic smears for a period comparable to the duration of PSP. Persistency of leukocytic smears in 4-day cycling rats pretreated with aLH from $8: 00 \mathrm{hr}$ on day 0 and then injected with PRL from as late as 8:00 hr on day 3 was significantly shorter than the duration of PSP $(p<0.01)$, and it was fairly close to the value for the animals treated with aLH alone. In 4-day cycling rats pretreated with aLH from 8:00 hr on day l, PRL injections from 19:00 hr on day 2, but not from 8:00 hr on day 3, again maintained leukocytic smears for a prolonged period comparable to the duration of PSP. However, in 4-day cycling rats pretreated with aLH from as late as 19:00 hr on day 1, PRL injections from 19:00 hr on day 2 failed to maintain leukocytic smears for more than 8.3 days. The persistency of leukocytic smears in this case was significantly shorter than the duration of PSP $(p<0.01)$.

In control NRS-pretreated 5-day cycling rats, as

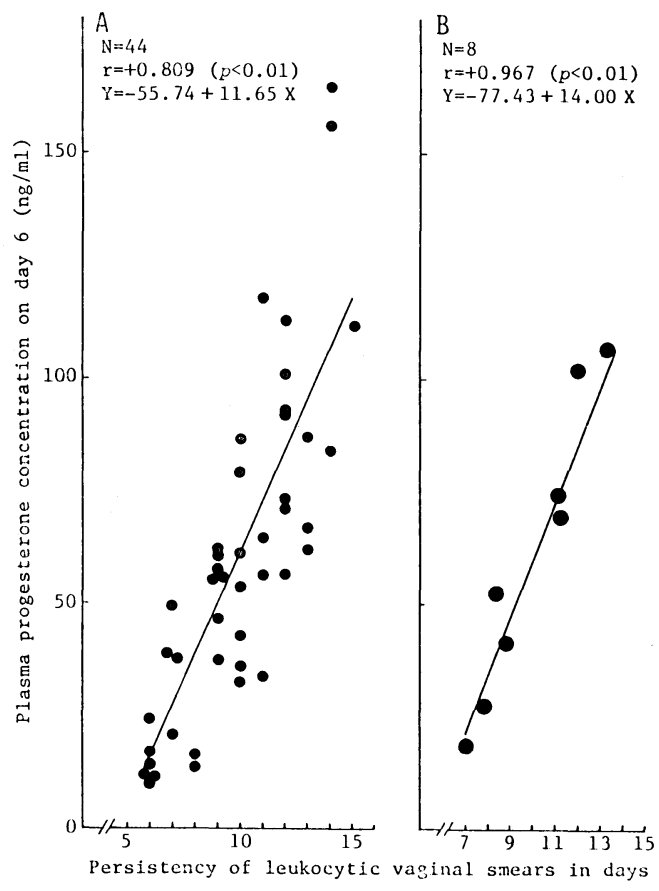

Fig. 2. Regression line obtained from a plot of persistency of leukocytic vaginal smears against plasma progesterone concentrations in individual rats (A) and experimental groups (B) treated with normal rabbit serum (NRS) or anti-LH serum $(\mathrm{aLH})$ in combination with prolactin (PRL). Eleven rats which had shown leukocytic vaginal smears for less than 6 days were excluded from the results. See legend to Table 2 .

in control 4-day cycling animals, PRL injections from 19:00 hr on day 2 failed to prolong the diestrous phase. Persistency of leukocytic smears in 5-day cycling rats pretreated with aLH from 8:00 hr on day 0 and subsequently injected with PRL from as late as $8: 00 \mathrm{hr}$ on day 3 was significantly shorter than the duration of PSP $(p<0.01)$, but it was significantly longer compared with the value for rats treated with aLH alone $(p<0.01)$. In 5-day cycling rats pretreated with aLH from 19:00 hr on day 1, however, PRL injections from 19:00 hr on day 2 maintained leukocytic smears for a period comparable to the duration of PSP. The persistency of leukocytic smears in this case was significantly longer than that in 4-day cycling animals subjected to the same treatment $(p<0.01)$.

Persistency of leukocytic vaginal smears was positively correlated with plasma progesterone 


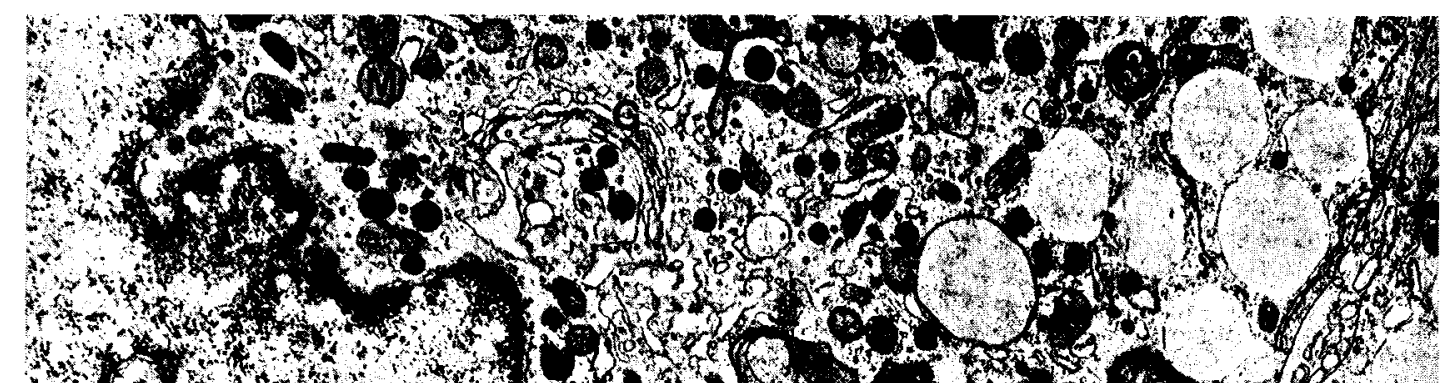

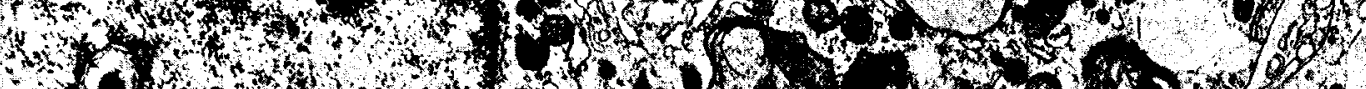

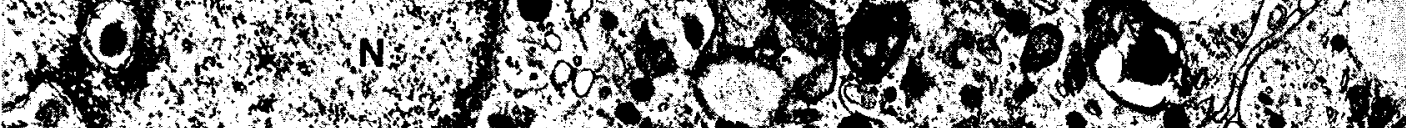

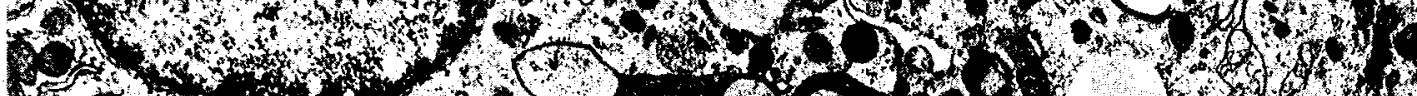

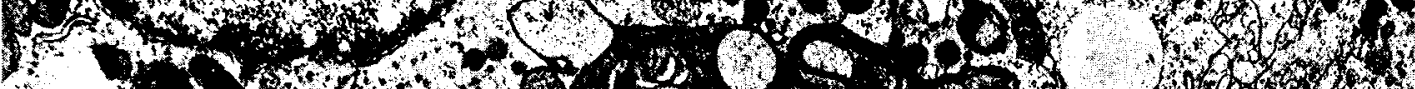
1)

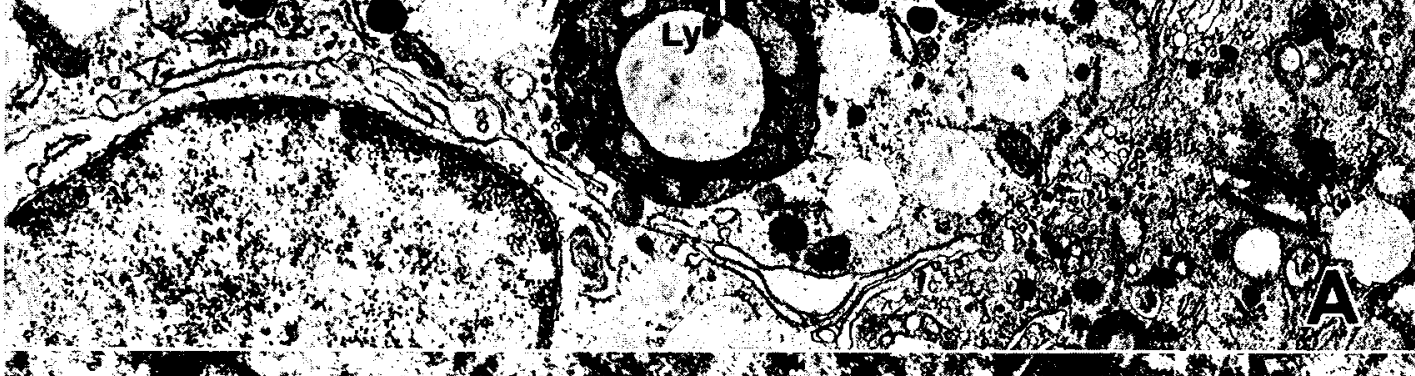

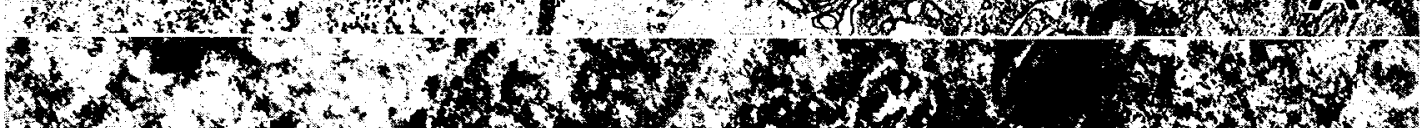

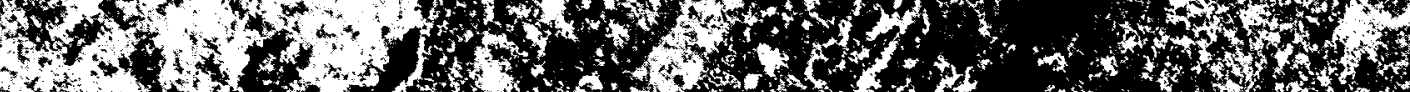

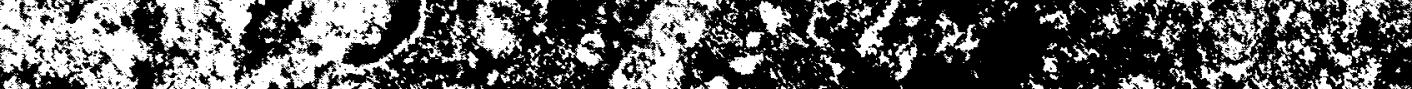

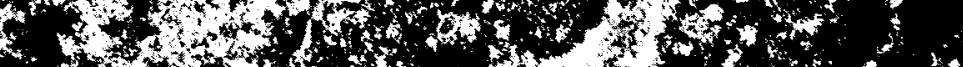

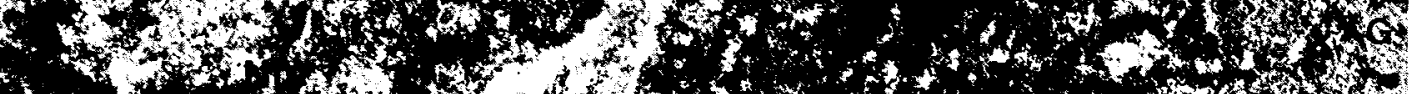

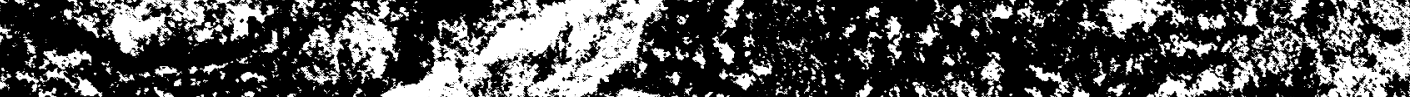

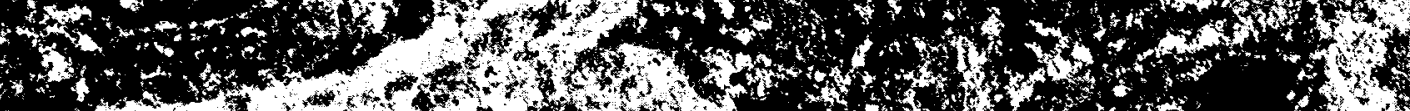

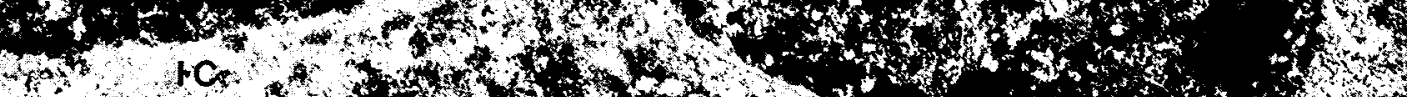

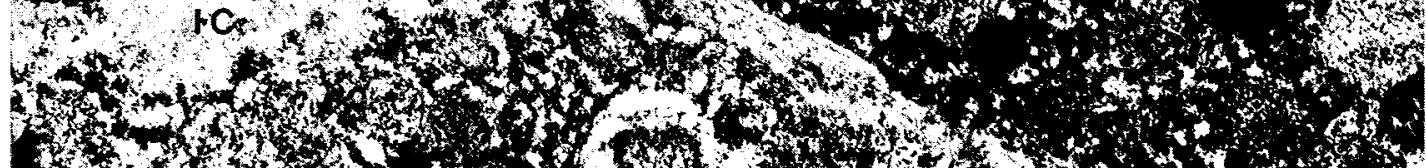

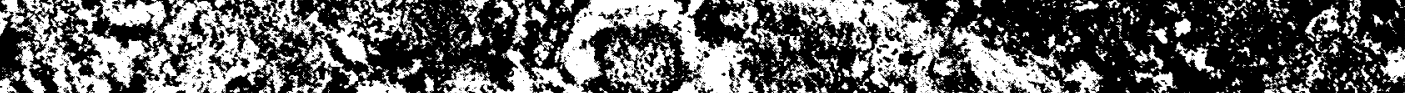

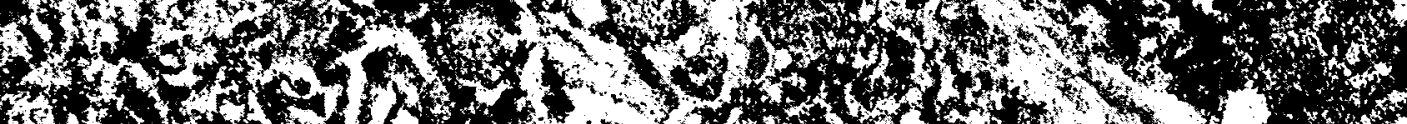

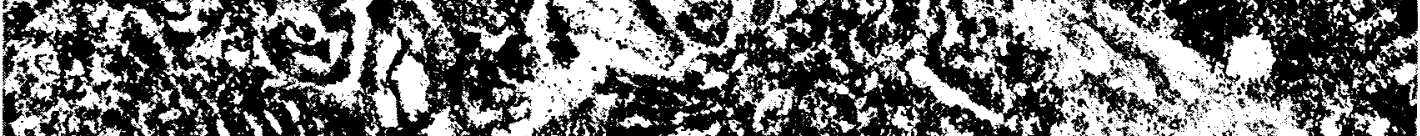

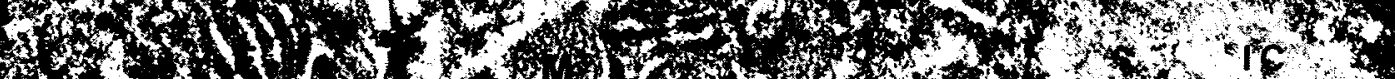

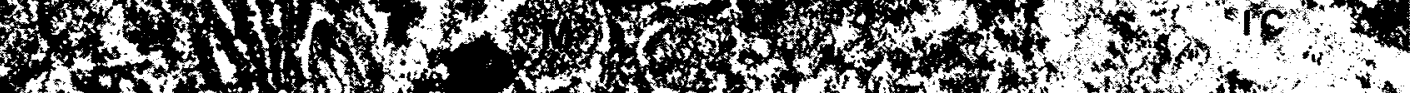

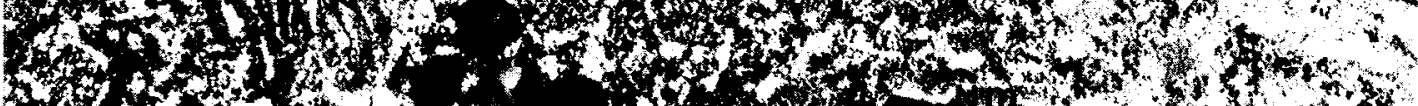

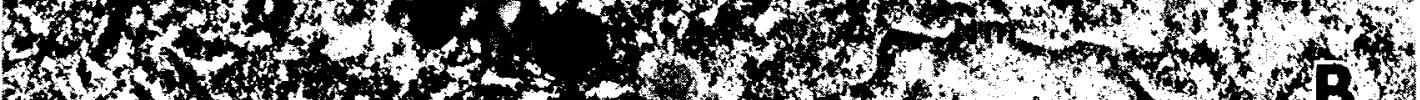

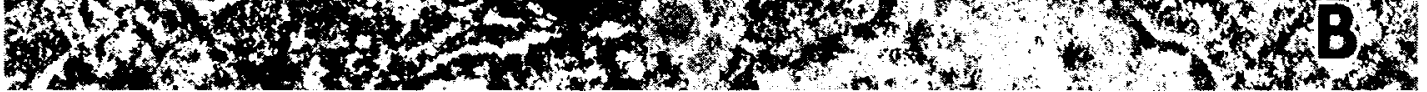




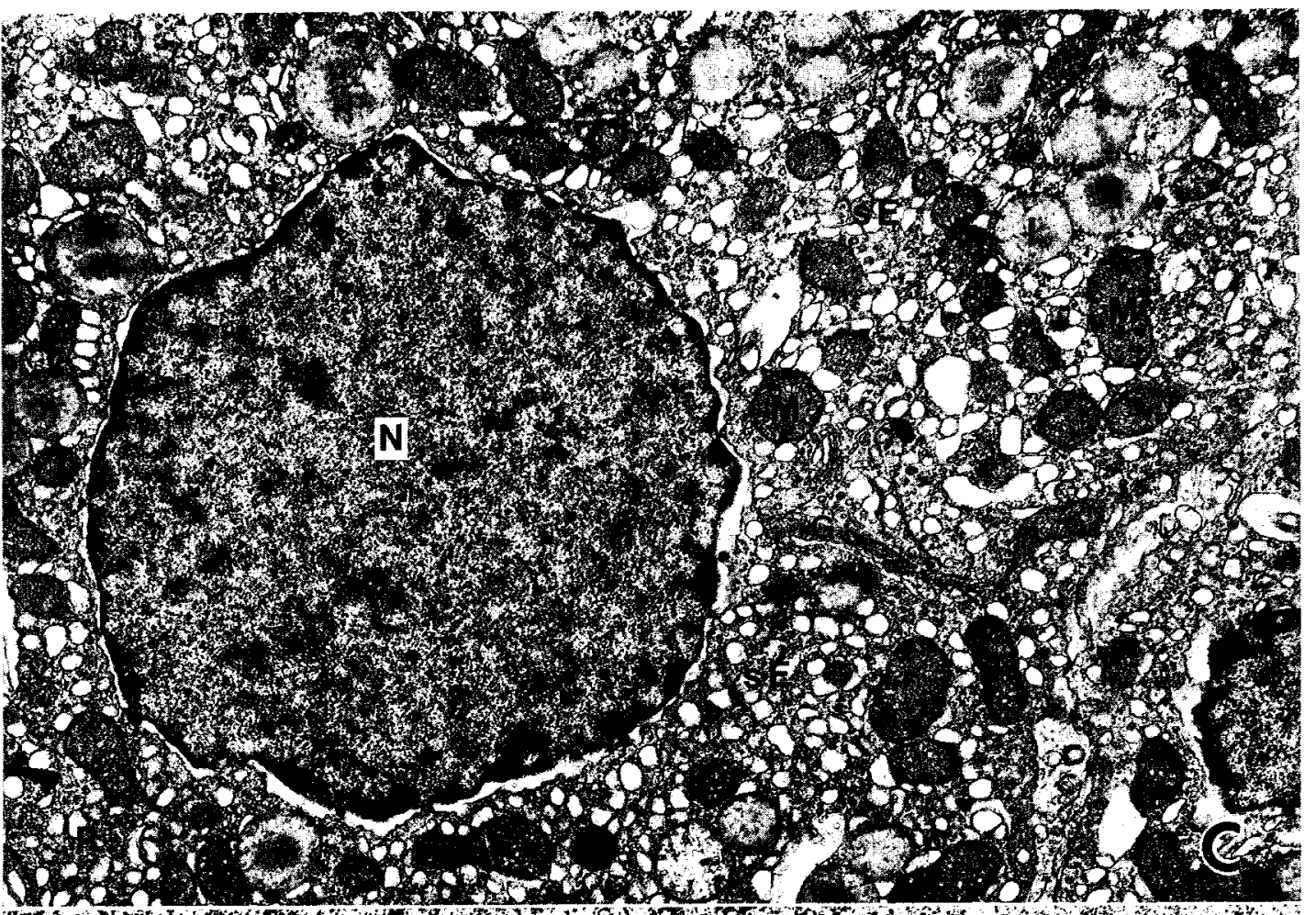

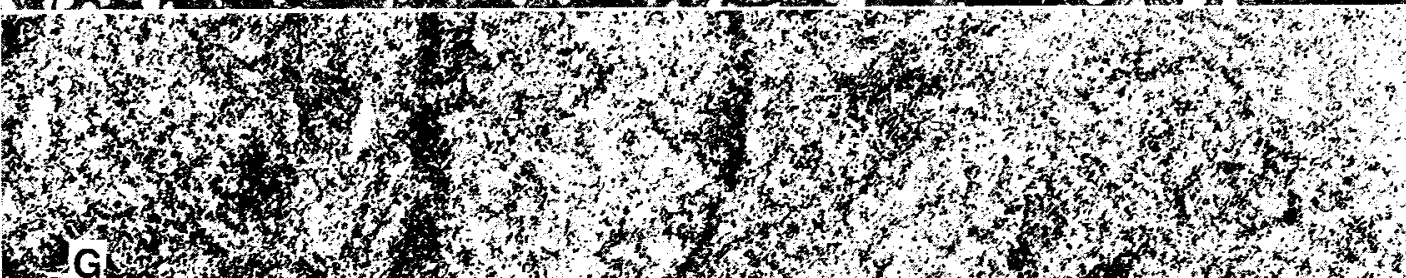

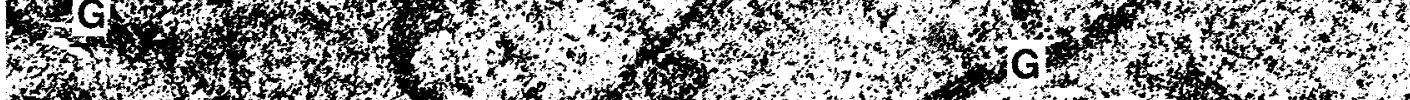
\% 2,

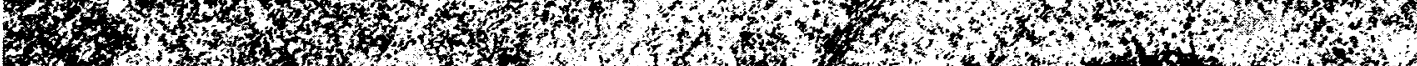

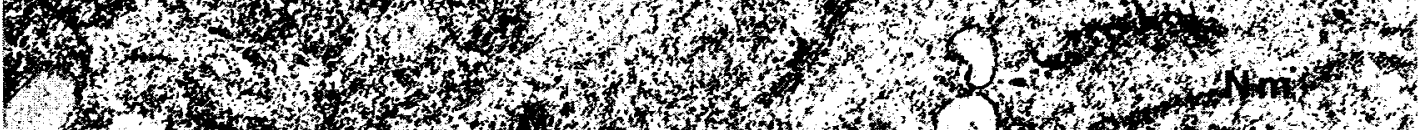

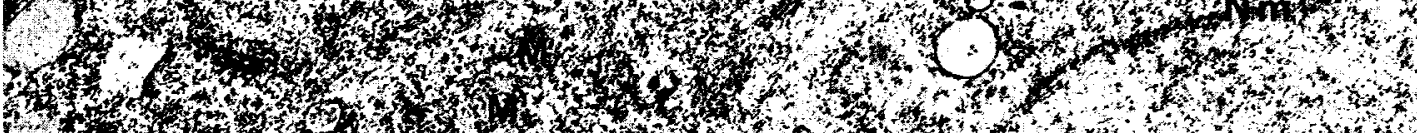

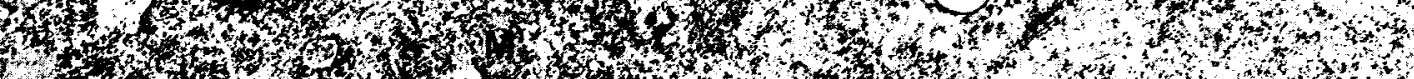

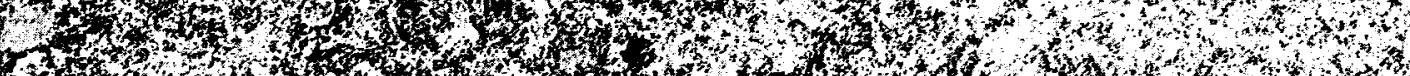

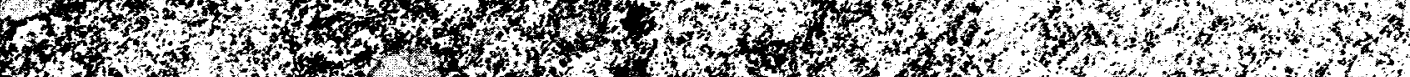

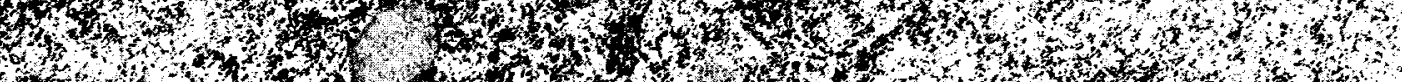

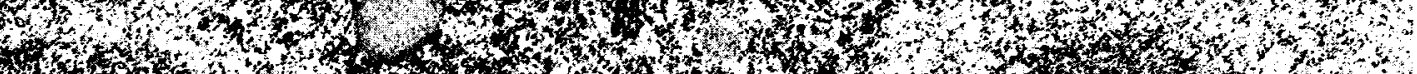

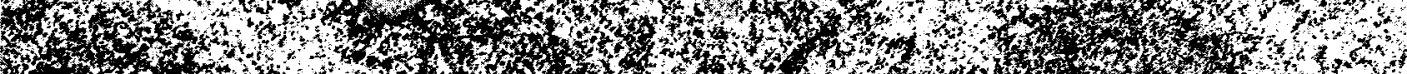

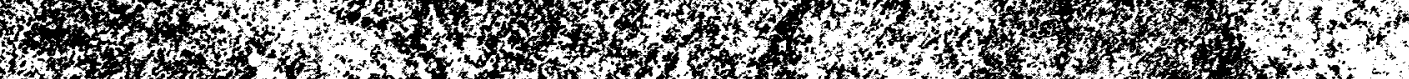
W 7.

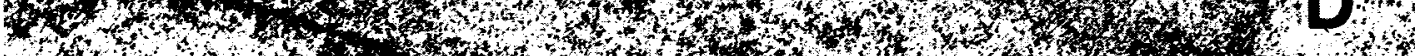


levels measured on day 6 in both individual rats (Fig. 2A) and experimental groups (Fig. 2B) treated with either combined NRS and PRL or combined aLH and PRL. Eleven animals which had shown leukocytic vaginal smears for less than 6 days were excluded from the results. Correlation coefficients were $+0.809(\mathrm{n}=44, p<0.01)$ for individual rats and $+0.967(n=8, p<0.01)$ for individual groups.

\section{Electron-microscopic Observations}

At 18:00 hr on day 2, the luteal cells from control NRS-treated 4-day cycling rats appeared pear-shaped or oval in profile. As shown in Fig. 3A, these cells had an irregularly shaped nucleus and relatively dark cytoplasm. The mitochondia were frequently characterized by coarse internal cristal membranes. Several dense bodies, presumably primary lysosomes, were visible adjacent to the Golgi complex, and there was a profusion of well-developed secondary lysosomes with the membranous organization. After osmication at $40^{\circ} \mathrm{C}$ for $48 \mathrm{hr}$, a selective localization of intense osmium impregnation was evident in the nuclear membrane, cristal membranes of the mitochondria and the endoplasmic reticulum, but not in the Golgi complex (Fig. 3B). An increase in the intercellular space was also noticed.

The luteal cells of 4-day cycling rats treated with aLH from 8:00 hr on day 1 were approximately isodiametric and contained a spherical nucleus, as shown in Fig. 3C. Their light cyto- plasm was characterized by large numbers of mitochondria and lipid droplets. The smoothsurfaced endoplasmic reticulum and Golgi complex were well-developed. The mitochondrion was spherical or dumbbell-shaped in outline in the cross-sections. Membranous tubular cristae and several vesicular cristae were contained within the organelle. The smooth-surfaced elements of the endoplasmic reticulum were more abundant than the ribosome-studded variety, and the elements showed no special orientation with respect to other components of the cell. Clusters of free ribosomes were also distinctly scattered over the cytoplasm. The Golgi complex had several layers together with numerous vesicles. As shown in Fig. 3D, osmium impregnation was particularly intense in the Golgi complex, the nuclear membrane and the internal cristal membranes of the mitochondria.

\section{Discussion}

The present investigation demonstrates that tonic levels of LH secreted during metestrus (day 1) of both 4- and 5-day estrous cycles suppress luteal progesterone secretion and reactivity to PRL and that the suppressive effect of $\mathrm{LH}$ is imposed approximately $12 \mathrm{hr}$ later in 5-day cycles than in 4-day cycles.

Plasma progesterone decreases from a peak level at 20:00 hr on metestrus (day 1) to a base line level by $6: 00 \mathrm{hr}$ on diestrus (day 2) in control 4-day cycling rats, which confirms previous find-

Fig. 3. Fine structure of the corpus luteum at $18: 00 \mathrm{~h}$ on diestrus (day 1) in 4-day cycling rats treated with normal rabbit s?rum (NRS) and anti-LH serum (aLH) from 8:00 hr on metestrus (day 1$) . \times 10,000$.

A: The lutein cells in the control NRS-treated rats appear elongated and oval shaped, containing an irregularly shaped nucleus $(\mathrm{N})$. The mitochondria $(\mathbf{M})$ frequently have coarse cristal membranes. Several dense bodies, presumably primary lysosomes (ly), are visible adjacent to the Golgi complex (G). A profusion of secondary lysosomes (Ly) with the membranous organization is also noticed.

B : Intense osmium impregnation is evident in the nuclear membrane ( $\mathrm{Nm}$ ), cristal membranes of the mitochondria (M) and endoplasmic reticulum (E), but not in the Golgi apparatus $(G)$ in the cells from the control animals. An increase in the intercellular space (IC) is also noticed.

C: The lutein cells from the aLH-treated animal are approximately isodiametric and contain a spherical nucleus $(\mathrm{N})$. The cytoplasm is packed with lipid droplets (L), well-develop:d smooth-surfaced $\epsilon$ ndoplasmic reticulum (sE), mitochondria (M) with many tubular cristae, and the Golgi complex (G) with several layers and numerous vesicles. Clusters of free ribosomes $(\mathrm{R})$ are scattered over the cytoplasm.

$\mathrm{D}$ : Osmium impregnation is particularly intense in the Golgi complex (G), the nuclear membrane $(\mathrm{Nm})$, and the internal cristal membranes of the mitochondria $(\mathrm{M})$ in the lutein cells from the aLH-treated animals. 
ings (Butcher et al., 1974; Smith et al., 1975; Nequin et al., 1979; Kaneko et al., 1986). In control 5-day cycling animals the steroid still remains at peak levels at $6: 00 \mathrm{hr}$ on diestrus (day 2), then declines to a low base line level by $18: 00 \mathrm{hr}$ on the same day, as previously reported (Roser and Block, 1969; van der Schoot and de Greef, 1976; Nequin et al., 1979; Kaneko et al., 1986). Thus, luteal progesterone secretion declines, relative to the preceding ovulation, about $12 \mathrm{hr}$ later in 5-day cycling rats than in 4-day cycling animals.

Sanchez-Criado et al. (1986) reported that a single injection of aLH at 8:00 hr on metestrus in a 4-day cycle prolongs luteal progesterone secretion up to $8: 00 \mathrm{hr}$ on diestrus. In the present investigation, daily aLH injections from $8: 00 \mathrm{hr}$, but not from 19:00 hr, on metestrus (day l) in a 4-day cycle prolong luteal progesterone secretion further up to $18: 00 \mathrm{hr}$ on diestrus (day 2). This finding indicates that tonic levels of $\mathrm{LH}$ secreted between 8:00 and 19:00 hr on metestrus play a decisive role in functional luteolysis of a new crop of corpora lutea in a 4-day cycle. In a 5-day cycle, on the other hand, aLH injections from as late as 19:00 hr on metestrus (day l) prolong luteal progesterone secretion beyond diestrus (day 2). This indicates that the luteolytic effect of $\mathrm{LH}$ is imposed at least $11 \mathrm{hr}$ later in 5-day cycling rats than in 4-day cycling animals. Therefore, the difference in timing of imposition of the luteolytic effect of LH appears causally related to the different timing of decline of luteal progesterone secretion between the rats with 4- and 5-day lengths. Since no differences in tonic LH levels during post-ovulatory stages have been measured between animals with two cycle lengths (Nequin et al., 1979), timing of expression of the luteal responsiveness to $\mathrm{LH}$ must be different between the 4-and 5-day cycles.

The present investigation quantifies luteal reactivity to PRL in terms of persistency of leukocytic vaginal smears and plasma progesterone levels on day 6 of the persistent leukocytic smears. A highly significant positive correlation is observed between the two parameters. The corpora lutea of control 4-day cycling rats remain fully reactive to PRL injections from 8:00 hr on diestrus (day 2). However, PRL injections from as late as 19:00 hr on the same day fail to prolong the diestrous phase in control 4- and 5-day cycling rats. Therefore, 5-day cycling rats as well as 4-day cycling animals must lose their luteal reactivity between 8:00 and 19:00 hr on diestrus. This is an unexpected finding because NikitovitchWiner and Everett (1958) show that the corpora lutea of 5-day cycle remain reactive to luteotropin (PRL) secreted from the autografted adenohypophysis later in their life span than do the corpora lutea of 4-day cycle. This discrepancy between the present data and Nikitovitch-Winer's may be explicable by strain-difference and/or differences in experimental conditions.

Four-day cycling rats pretreated with aLH from 8:00 hr on metestrus (day 1 ) preserve a full luteal reactivity to PRL injection from $19: 00 \mathrm{hr}$ on diestrus (day 2), when control animals lose their luteal reactivity. However, 4-day cycling animals pretreated with aLH from 19:00 hr on metestrus (day 1) show a sub-maximal reactivity to PRL injected from 19:00 hr on diestrus (day 2). Contrarily, in a 5-day cycle, aLH pretreatment from as late as 19:00 hr on metestrus (day 1) maintains a full reactivity to PRL injections from 19:00 hr on diestrus (day 2). These findings indicate that tonic levels of LH secreted during metestrus also suppress luteal reactivity to PRL in both 4 - and 5-day cycles, and the suppressive effect of $\mathrm{LH}$ is imposed at least $11 \mathrm{hr}$ later in 5-day cycles than in 4-day cycles.

The preovulatory LH surge "potentiates" progestational ability of the newly formed corpora lutea since the magnitude of the preovulatory LH surge is about 10 times that required for ovulation (Turgeon and Barraclough, 1973), and since hypophysectomy (deprivation of both $\mathrm{LH}$ and PRL) on estrus in a 4-day cycle does not affect luteal progesterone secretion (Uchida et al., 1969; Sanchez-Criado, 1986). Either a single injection of bromoergocriptine (deprivation of PRL) or hypophysectomy on estrus, however, abolishes a prolongation of luteal progesterone secretion induced by LH deprivation during metestrus in a 4-day cycle (Sanchez-Criado et al., 1986). In the present investigation, daily aLH injections from as early as 8:00 hr on estrus (day 0) in a 4-day cycle fail to prolong luteal progesterone secretion. Thus, in absence of either LH or PRL during estrus in a 4-day cycle, luteal progesterone secretion declines to a base line on the morning of diestrus even when the luteolytic effect of $\mathbf{L H}$ secreted during metestrus is eliminated. This 
indicates that both $\mathrm{LH}$ and PRL act synergistically during estrus, as they do during PSP (Hashimoto et al., 1975), to "enhance" luteal potential ability to secrete progesterone in 4-day cycling rats.

Deprivation of $\mathrm{LH}$ from as early as 8:00 hr on estrus in a 5-day cycle prolongs luteal progesterone secretion (see Table 1). A single injection of bromoergocriptine on estrus in a 5 -day cycle, however, results in a significant decrease in luteal progesterone secretion by the morning of diestrus, shortening the cycle by 1 day (Boehm et al., 1984). Therefore, "enhancement" of potential progestational ability of the corpora lutea in a 5-day cycle may be greatly, if not entirely, dependent upon PRL secretion during estrus rather than upon $\mathrm{LH}$ secretion during the stage. This is probably related to the finding that 5-day cycling rats can be differentiated from 4-day cycling animals by not only their lower preovulatory LH levels but also their higher preovulatory levels of PRL (Hashimoto et al., 1987).

At 18:00 hr on diestrus, the luteal cells of control NRS-treated 4-day cycling rats appears elongated. These cells contain an irregularly shaped nucleus, mitochondria with coarse internal cristal membrane, numerous lysosomes and poorly osmicated Golgi complex. The interstices among the cells increase. Structural luteolysis, therefore, is apparent in the luteal cells of control animals.

The luteal cells of 4-day cycling rats treated with aLH from 8:00 hr on metestrus (day 1) are packed with lipid droplets, mitochondria with many tubular cristae, well-developed smoothsurfaced endoplasmic reticulum. Mitochondria are well known to have cholesterol side chain cleaving enzymes. The structural difference in the organelle between control and aLH-treated rats may be related to enzyme content. The amount of smooth-surfaced endoplasmic reticulum, which posseses $\Delta^{5}$ - $3 \beta$-hydroxysteroid dehydrogenase involved in conversion of pregnenolone to progesterone, is correlated with increased steroid hormone production in pigs (Cavazos et al., 1969) and pregnant rats (Long, 1973). A similar correlation is found by the present investigation. In addition, the Golgi complex of luteal cells in aLH-treated rats is well developed and shows intense osmium impregnation. The organelle increases in size during the course of pregnancy in the rat (Long, 1973), although its role in luteal steroid secretion remains unclear. The prolongation of luteal progesterone secretion and preservation of luteal reactivity to PRL by metestrous LH deprivation, therefore, has a structural basis. The mechanism of functional and structural luteolysis caused by LH secreted during metestrus should be investigated.

\section{Acknowledgements}

The authors wish to thank Dr. A. F. Parlow and the Rat Pituitary Hormone Distribution Program, NIADDK, NIH, USA, for ovine LH preparation (NIH-LH 20). Their appreciation is also expressed to Edwin Bruce Jones, M. Ed., for his valuable advice during the preparation of the manuscript.

\section{References}

Acker G, Alloiteau J-J (1968) Le tout jaune cyclique de la ratte estil fonctionnel sans soutien hypophysaire? CR Soc Biol 162: 29-33.

Boehm N, Plas-Roser S, Aron Cl (1984) Prolactin and the control of cycle length in the female rat. Acta Endocrinol 106: 188-192.

Butcher RL, Collins WE, Fugo NW (1974) Plasma concentrations of $\mathrm{LH}, \mathrm{FSH}$, prolactin, progesterone and estradiol-17 $\beta$ throughout the 4-day estrous cycle of the rat. Endocrinology 94: 1704-1708.

Cavazos LF, Andersron LL, Belt WD, Henricks DM, Kraeling RR, Melampy RM (1969) Fine structure and progesterone levels in the corpus luteum of the pig during the estrous cycle. Biol Reprod 1: 83-106.

Furudate S, Hashimoto I, Hosi T (1975) Secretion of ovarian progestins in the 5-day cyclic rat. Jpn $J$ Anim Reprod 20: 144-148 (In Japanese).

Hashimoto I, Asano T, Wiest WG (1975) Progestational function of perifused rat corpora lutea. Endocrinology 96: 421-430.

Hashimoto I, Isomoto N, Eto M, Kawaminami M, Sunazuka C, Ueki N (1987) Preovulatory secretion of progesterone, luteinizing hormone and prolactin in 4-day and 5-day cycling rats. Biol Reprod 36: 599-605.

Hashimoto I, Kawaminami M, Mutoh K, Wakuri H (1984) Chronological biphasic action of luteinizing hormone $(\mathbf{L H})$ on progestational function of rat corpora lutea. Excerpta Med Int Congr Ser 652: 628 (Abstr).

Kaneko S, Sato N, Sato K, Hashimoto I (1986) Changes in plasma progesterone, estradiol, follicle-stimulating hormone and luteinizing hormone during diestrus and ovulation in rats with 5-day estrous cycles: Effect of antibody against progesterone. 
Biol Reprod 34: 488-494.

Long JA (1973) Corpus luteum of pregnancy in the rat-Ultrastructural and cytochemical observations. Biol Reprod 8: 87-99.

Nequin LG, Alvarez J, Schwartz NB (1979) Measurement of serum steroid and gonadotropin levels and uterine and ovarian variables throughout 4-day and 5-day estrous cycles in the rat. Biol Reprod 20: 659-670.

Nikitovitch-Winer M, Everett JW (1958) Comparative study of luteotropin secretion by hypophysial autotransplants in the rat. Effects of site and stages of the estrous cycle. Endocrinology 62: $522-532$.

Okudaira T, Kanayama A, Kawaminami M, Hashimoto I (1983) Regulation by preovulatory LH surge of corpora luteal progesterone secretion in cycling rats. Program of the 96th Meeting of the Japanese Society of Veterinary Science p. 51 (Abstr, in Japanese).

Roser S, Block RB (1969) Variations du taux de la progesterone plasmatique au cours de cycles de 5 jours chez la ratte. CR Hebd Seances Acad Sci 268: $1318-1320$.

Sanchez-Criado JE, Lopez F, Aguilar E (1986) Pituitary regulation of corpus luteum progesterone secretion in cycling rats. Endocrinology 119: 1083-1088.

Sawano F, Fujita H (1980) Characteristic reaction of the mouse adrenal cortical cell to osmium impregnation. Arch Histol Jpn 43: 365-372.

Smith MS, Freeman ME, Neill JD (1975) The control of progesterone secretion during the estrous cycle and early pseudopregnancy in the rat: Prolactin, gonadotropin and steroid levels associated with rescue of the corpus luteum of pseudopregnancy. Endocrinology 96: 219-226.

Turgeon J, Barraclough AC (1973) Temporal patterns of LH release following graded preoptic electrochemical stimulation in proestrous rats. Endocrinology 92: 755-761.

Uchida K, Kadowaki M, Miyake T (1969) Ovarian secretion of progesterone and $20 \alpha$-hydroxypregn4-en-3-one during rat estrous cycle in chronological relation to pituitary release of luteinizing hormone. Endocrinol Jpn 16: 227-237.

van der Schoot P, de Greef, WJ (1976) Dioestrous progesterone and pro-oestrous luteinizing hormone in 4- and 5-day cycles of female rats. J Endocrinol 70: $61-68$.

van der Schoot P, Uilenbrock JThJ (1983) Reduction of 5-day cycle length of female rats by treatment with bromocriptine. J Endocrinol 97: 83-89.

\title{
排卵後の黄体形成ホルモン $(\mathbf{L H})$ 分泌による ラット発情周期黄体機能の調節
}

\author{
橋本禱・相澤 勝也・瀬谷 祐一・菰田康 \\ 東野 浩司 - 武藤顕一郎* - 汾陽 光盛 \\ 北里大学獣医畜産学部 獣医生理学教室 獣医解剖学教室*
}

四日及び五日周期ラットの発情周期黄体 (CL)の progesterone (P) 分泌の持続性と prolactin (PRL) に対す る反応性に及ぼす抗羊 $\mathrm{LH}$ 家免血清 $(\mathrm{aLH})$ 投与の影響 を検讨した。四日周期の発情期(E) から 1 日 2 回，8時 と19時に $\mathrm{aLH}$ を連続投与しても，血漿 $\mathrm{P}$ は対照四日周 期と差がなく, 発情休止期 (D) 6 時に減少した。発情後 期(M) 8 時から aLH を投与した場合には，D 18時に 打いても P は減少しなかった。 M 19時から aLH を投与 すると, D 18時には P が減少した。対照五日周期の $\mathrm{P}$ は，D 6 時でも対照四日周期より有意に高く，D18時に 減少した。この五日周期では，E 8 時及びM19時の何れ の侍点からの $\mathrm{aLH}$ 投与によっても，D18時に打ける $\mathrm{P}$ の減少が観察されなくなった。

対照四日周期で，PRL 10 IUをD 8 時から 1 日 2 回, 8 時と19時に連続投与すると，正常偽妊娠（PSP）に匹 督するDの延長と P の増加が観察された。しかし， D 19
時から PRL を投与した場合には，四日及び五日周期共 に，その周期ではDの延長は起らず，対照周期の CL の PRL に対する反応性は, D19時には消失することが知ら れた。四日周期で， EあるいはMの 8 時からの aLH 投 与に続いて，D19時から PRL を投与したところ, PSP と同様なDの延長と P の増加が招来された。D19時から の PRL 投与に先行して, M19時から $\mathrm{aLH}$ を投与した場 合には，Dの延長期間は PSP より有意に短く，Pも低 かった。五日周期では, 同様な処置により PSP に匹敵 するDの延長と P の增加が観察された。電子顕微鏡観察 でも, CL 細胞機能に符合する知見が得られた。以上の 成績から，四日周期 $\mathrm{E}$ の $\mathrm{LH}$ 分泌は， CL の P 分泌能を 高めるよう働いていること, また両周期の M以後に分泌 される LH は，CL 機能を抑制するよう作用しており， その抑制作用は，五日周期では四日周期より少くとも 11 時間遅れて発現することが示唆された。 